\title{
HUBUNGAN KADAR SOD DAN JUMLAH SEL RADANG AKUT AKIBAT PEMBERIAN TEPUNG PSPL PADA TIKUS YANG DIPAPAR ASAP ROKOK
}

\author{
Inggita Kusumastuty, Fajar Ari Nugroho, Leni Budhi Harti \\ Jurusan Gizi Fakultas Kedokteran Universitas Brawijaya \\ inggita.kusuma@gmail.com
}

\begin{abstract}
ABSTRAK
Daun ubi jalar unggu (Purple Sweet Potato Leaves, PSPL) mengandung antioksidan yang tinggi dan dapat memperbaiki tingkat stres oksidatif akibat tingginya oksidan di dalam tubuh. Tujuan penelitian ini adalah mengetahui hubungan SOD dengan jumlah sel radang akut alveoli paru tikus yang diberi PSPL dan dipapar asap rokok. Penelitian ini menggunakan rancangan Randomized Post Test Control Design dengan menggunakan sampel tikus putih sebanyak 30 ekor. Kelompok perlakuan dipapar asap rokok dan diberikan tepung PSPL sejumlah 0,07 g (P1); 0,14 g (P2) dan 0,28 g (P3) selama 30 hari. Kadar SOD dan jumlah sel radang akut alveoli paru kemudian diukur. Hasil penelitian ini menunjukkan bahwa PSPL dapat meningkatkan SOD dan menurunkan jumlah sel radang akut alveoli paru pada tikus. Ada hubungan antara kadar SOD dengan jumlah sel radang akut alveoli paru, dimana semakin tinggi kadar SOD maka semakin rendah jumlah sel radang akut alveoli paru.
\end{abstract}

Kata kunci: PSPL, SOD, antioksidan

\section{ABSTRACT}

\section{THE RELATION BETWEEN SOD AND NUMBER OF ACUTE INFLAMMATORY CELLS IN RATS WITH PSPL POWDER TREATMENT AND CIGARETTE SMOKE EXPOSURE}

Purple sweet potato leaves (PSPL) contains polyphenols in high concentration that lead to improve oxidative stress levels due to high oxidant present in the body. The purpose of this study was to determine the relationship between SOD with the number of acute inflammatory cells of lung alveoli rats that was fed with PSPL and exposedto cigarette smoke. This research was Randomized Post Test Control Design using 30 white rats. The treatment groups exposed to cigarette smoke and PSPL's powder that they were $0.07 \mathrm{~g}(\mathrm{P} 1), 0.14 \mathrm{~g}(\mathrm{P} 2)$ and $0.28 \mathrm{~g}(\mathrm{P} 3)$ in 30 days. The level of SOD and acute inflammatory cell lung alveoli was measured. The result showed that PSPL powder was able to increase SOD and to decrease the number of acute inflammatory cells of the lung alveoli of rats. There was a correlation between the level of SOD and the number of acute inflammatory pulmonary alveoli, where as the higher levels of SOD induced the lower number of acute inflammatory pulmonary alveoli.

Keywords: PSPL, SOD, antioxidant

\section{PENDAHULUAN}

A sap rokok merupakan salah satu polutan yang berupa gas. Di dalam asap rokok terkandung bahan kimia antara lain nikotin, karbon monoksida, tar dan euggenol. Nikotin yang masuk ke dalam tubuh dalam dosis yang besar akan menyebabkan suatu kematian. Sedangkan tar yang terdapat pada asap rokok mengandung bahan-bahan kimia yang telah dibuktikan bersifat karsinogen. Karbon monoksida adalah komponen utama pada asap rokok yang memiliki kemampuan berikatan dengan $\mathrm{Hb}$ yang jauh lebih kuat dibanding oksigen. Sehingga rokok dapat menimbulkan dampak buruk terhadap kesehatan manusia. ${ }^{1}$
Asap rokok yang terhisap dalam tubuh mengandung radikal bebas. Radikal bebas pada asap rokok diperkirakan dalam satu kali hisap sebanyak $10^{14}$ molekul yang masuk kedalam tubuh. ${ }^{2} \mathrm{Hal}$ ini akan menyebabkan stres oksidatif yaitu kondisi di mana beban oksidan yang berlebih pada tubuh, ketidak seimbangan antara produksi reactive oxygen species (ROS) dan mekanisme pertahanan antioksidan pada tubuh.3,4 Peningkatan jumlah ROS akan menurunkan kadar Superoksid Dismutase (SOD). SOD merupakan enzim antioksidan yang memegang peranan penting dalam melindungi sel dari stres oksidatif. SOD ini secara tidak langsung akan menjaga keseimbangan dari berbagai macam radikal bebas yang bersifat toksik bagi sel. ${ }^{5}$ 
Selain hal tersebut, asap rokok juga akan menyebabkan beban oksidan yang sangat berlebihan pada jaringan termasuk jaringan paru. ${ }^{6}$ Stres oksidatif sering terkait dengan puncak terjadinya kerusakan jaringan. Kerusakan jaringan ini akan memicu terjadinya reaksi inflamasi dan berakibat pada terjadinya pelepasan chemokine, sejenis protein yang mengatur perjalanan leukosit dan membantu penarikan leukosit ke tempat terjadinya inflamasi. ${ }^{7}$ Proses inflamasi akan mengakibatkan gangguan pada berbagai jaringan yaitu salah satunya adalah jaringan paru. Pada jaringan paru, terjadi peningkatan jumlah sel radang dan kerusakan alveoli. ${ }^{8}$ Dalam hal ini, paparan asap rokok dapat menyebabkan penurunan fungsi paru-paru dan akan memicu peningkatan jumlah makrofag dan neutrofil pada jaringan paru-paru. ${ }^{9}$

Secara alami, tubuh telah memiliki antioksidan yang menghambat oksidasi. Akan tetapi, apabila paparan radikal bebas terlalu banyak, antioksidan alami tersebut tidak mampu untuk mengatasinya. Dalam keadaan seperti ini maka tubuh memerlukan suplai antioksidan dari luar tubuh. Salah satunya adalah daun ubi jalar ungu. Daun ketela ungu atau Purple Sweet Potato Leaves (PSPL) merupakan tanaman yang mudah tumbuh di daerah tropis. Daun ini mengandung polifenol, flavonoid, dan karotenoid yang paling tinggi di antara sayursayuran lainnya, yang memiliki kemampuan menangkap radikal bebas. Beberapa penelitian sebelumnya menunjukkan bahwa polifenol berfungsi untuk meningkatkan status antioksidan dan respon imun. Kandungan karotenoid pada PSPL juga dapat meningkatkan aktivitas immunemodulator. $10,11,12,13$

Adanya peran polifenol sebagai antioksidan pada PSPL ini diharapkan dapat memperbaiki kondisi akibat paparan asap rokok. Sehingga perlu dibuktikan dalam sebuah penelitian. Tujuan dari penelitian ini adalah ingin membuktikan hubungan pemberian PSPL terhadap SOD dan sel radang akut pada alveoli yang dipapar asap rokok.

\section{METODE PENELITIAN}

Penelitian ini menggunakan pendekatan true eksperimental. Rancangan penelitian yang digunakan adalah Randomized Post Test Only
Control Group Design. Sampel yang digunakan dalam penelitian ini adalah 30 ekor tikus. Perhitungan jumlah sampel tersebut berdasarkan rumus Federer dengan menggunakan lima kelompok perlakuan. ${ }^{14}$ Penelitian ini dilakukan pada tikus jenis Rattus Novergicus Strain Wistar yang dikarenakan tikus merupakan hewan coba yang memiliki kemiripan dengan manusia yaitu mamalia, pemakan segala (omnivore), mudah berkembang biak, mudah perawatannya serta mempunyai metabolisme mirip manusia. ${ }^{15}$ Tikus yang digunakan dalam penelitian ini berdasarkan kriteria inklusi yaitu jenis kelamin jantan, berusia 6-8 minggu, berat badan 140250 gram dan dalam keadaan sehat selama penelitian dan tidak mendapat pengobatan sebelumnya. Selama penelitian tikus dipelihara di Laboratorium Farmakologi Fakultas Kedokteran Universitas Brawijaya Malang. Penelitian ini telah lolos etik dari Komisi Etik Penelitian Kesehatan Fakultas Kedokteran Universitas Brawijaya dengan No. 072/EC/KEPK-S2/02/2013.

Pada penelitian ini, tikus dirandomisasi, kemudian dibagi menjadi 5 kelompok perlakukan yaitu kelompok perlakuan diet normal $(\mathrm{K}+)$, kelompok perlakuan diet normal dengan paparan asap rokok (K-), kelompok perlakuan dengan paparan asap rokok disertai pemberian PSPL dalam dengan dosis yang berbeda, yaitu $\mathrm{P} 1=0,07 \mathrm{~g}, \mathrm{P} 2=0,14 \mathrm{~g}$ dan $\mathrm{P} 3$ $=0,28 \mathrm{~g}$ per hari.

\section{Paparan asap rokok}

Pemaparan asap rokok pada tikus dilakukan dengan menggunakan asap rokok kretek dari merek tertentu yang telah ditetapkan dengan bantuan alat berupa 'smoking pump'. Smoking pump adalah alat yang terdiri dari mesin pompa dan pipa yang dapat memompakan asap rokok yang volumenya dapat diatur sesuai dengan kecepatan mesin pompa. Dosis pemaparan setiap 3 ekor tikus adalah satu batang rokok perhari selama 30 hari selama 5 menit karena pemaparan asap rokok selama 8 menit dapat menyebabkan gangguan napas. ${ }^{16}$ Pemaparan asap rokok untuk kelompok perlakuan $\mathrm{P} 1, \mathrm{P} 2$ dan P3. Pemaparan dilakukan 2,5 jam setelah pemberian daun ubi jalar ungu untuk menghindari efek samping tidak mau makan. ${ }^{16}$ 


\section{Pemberian PSPL}

Pemberian PSPL ini diberikan dalam bentuk tepung dengan tujuan untuk memudahkan pemberian pada kelompok perlakuan P1, P2 dan P3. Pemberiannya pada tikus melalui sonde agar $100 \%$ dapat dihabiskan oleh tikus. Dosis yang diberikan adalah 0,07 g/hari untuk kelompok perlakuan $\mathrm{P} 1$,dan $0,14 \mathrm{~g} /$ hari untuk kelompok perlakuan P2 serta 0,28 g/hari untuk kelompok perlakuan P3. Pemberian dosis ini diberikan selama 30 hari. Dasar Pemberian dosis standar (P1) berdasarkan perhitungan kandungan polifenol pada tepung PSPL. Dari uji pendahuluan didapatkan bahwa tepung PSPL yang digunakan dalam penelitian ini mengandung 1805 mgGAE per 100 gram. Sedangkan dosis pada kelompok perlakuan P2 dan P3 ditentukan berdasarkan deret hitung dari dosis kelompok perlakuan P1.

\section{Pemeriksaan Kadar SOD}

Kadar SOD diukur dari sampel serum tikus dari semua kelompok perlakuan. Kadar SOD diketahui dengan mengukur hasil oksidasi NBT menjadi formazen menggunakan spektrofotometer panjang gelombang $580 \mathrm{~nm}$.

\section{Sel Radang Akut Alveoli Paru Tikus Prosedur Pengambilan Organ}

Tikus yang akan dibedah dibius menggunakan kapas yang sudah ditetesi eter terlebih dahulu. Tikus dibiarkan lemas, kemudian dibedah dan diambil organ paru tikus. Potongan paru ini kemudian dimasukkan dalam larutan formalin $10 \%$, untuk kemudian dibuat sediaan histopatologi dengan pengecetan hematoxyclyn-eosin (HE).

\section{Prosedur Penghitungan Jumlah Sel Radang Akut di Alveoli Paru}

Pengumpulan data dilakukan dengan pengamatan secara mikrokopis terhadap 29 preparat histopatologi alveoli tikus dengan pembesaran 400x. Setiap preparat dipilih dari 10 lapangan pandang untuk dihitung jumlah sel radang yang tampak. Lapangan pandang dipiliih secara acak dan jumlah sel radang dihitung dengan cara manual.

\section{Analisa Data}

Data kadar SOD dan Jumlah sel radang akut di alveoli paru dianalisa menggunakan uji korelasi Spearman dikarenakan data tidak terdistribusi secara normal. Uji tersebut untuk membuktikan ada tidaknya hubungan, kekuatan hubungan dan arah hubungan antara kadar SOD dan jumlah sel radang akut di alveoli paru.

\section{HASIL}

Hasil penelitian menunjukkan perbedaan kadar SOD dan jumlah sel radang akut di alveoli tikus setelah perlakuan selama 30 hari pada masing-masing kelompok perlakuan. Kode pada gambar merujuk pada kelompok perlakuan berikut: diet normal $(\mathrm{K}+)$, diet normal dan paparan asap rokok (K-), diet normal, paparan asap rokok dan pemberian tepung PSPL berturut-turut 0,07 g/hari (P1), 0,14 g/hari (P2) dan $0,28 \mathrm{~g} /$ hari (P3).

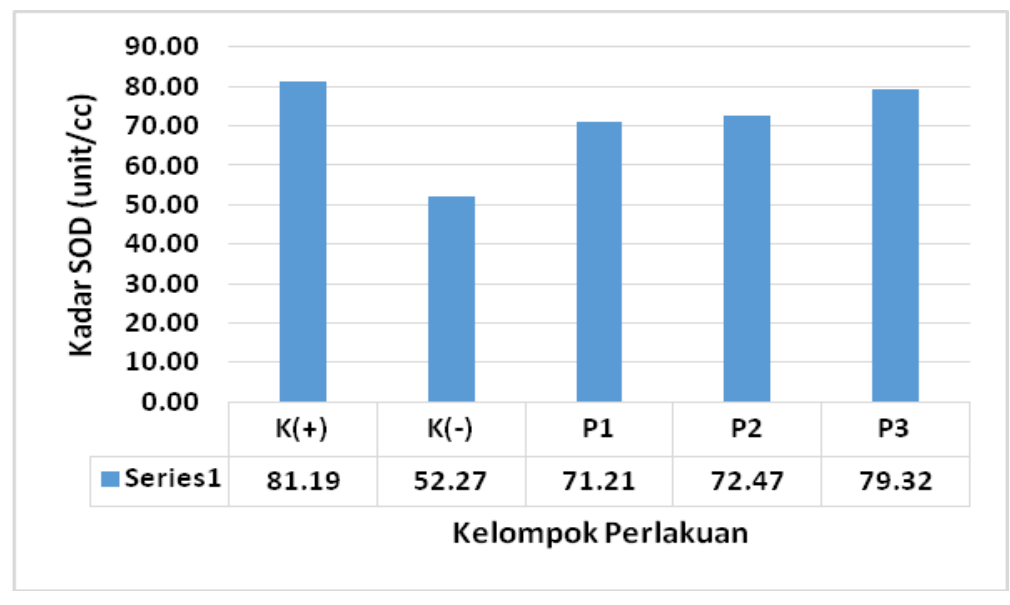

Gambar 1

Rata-rata Kadar SOD pada Semua Kelompok Perlakuan 


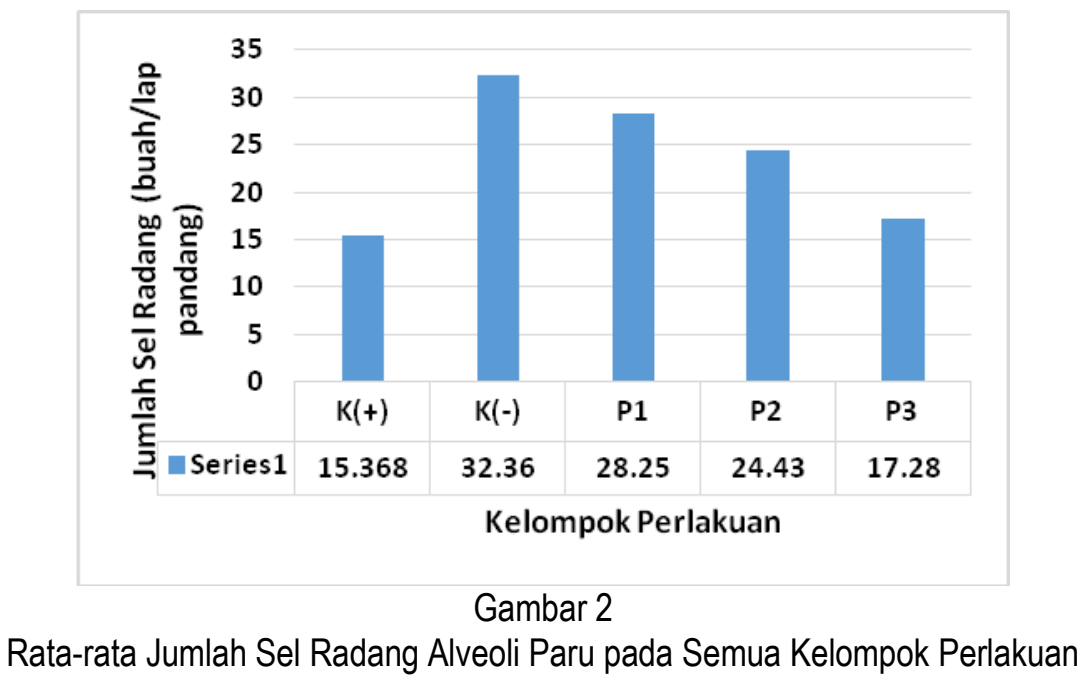

Gambar 1 menunjukkan bahwa rata-rata kadar SOD tertinggi pada kelompok perlakuan K+ yaitu sebesar 81,19 unit/cc. Kadar SOD terendah terdapat pada kelompok perlakuan Kyaitu sebesar 52,27 unit/cc. Sedangkan pada kelompok yang diberikan PSPL terdapat meningkatan dengan bertambahnya dosis tepung PSPL yang diberikan, yaitu kadar SOD pada kelompok perlakuan P1, P2 dan P3 secara berturut-turut adalah sebagai berikut 71,21 unit/cc, 72,47 unit/cc dan 79,32 unit/cc.

Gambar 2 menunjukkan bahwa rata-rata sel radang alveoli tertinggi pada kelompok perlakuan K- yaitu sebesar 32,36 buah. Ratarata terendah didapatkan pada kelompok perlakuan K+ yaitu sebesar 15,37 buah. Pada kelompok perlakuan yang diberikan tepung PSPL menunjukkan penurunan jumlah sel radang alveoli. Semakin banyak dosis tepung PSPL yang diberikan maka semakin rendah jumlah sel radang pada alveoli paru yaitu pada kelompok P1, P2 dan P3 secara berturut turut adalah sebagai berikut 28,25 buah, 24,43 buah dan 17,28 buah.

Dari analisa korelasi spearman yang dilakukan menunjukkan bahwa terdapat hubungan antara kadar SOD dengan jumlah sel radang akut alveoli paru $(p=0,000)$. kekuatan hubungan antara kadar SOD dengan jumlah sel radang akut alveoli tersebut sangat tinggi $(r=$ 0,937 ) dan arah hubungan tersebut berlawanan arah. Maksudnya adalah semakin tinggi kadar SOD maka semakin rendah jumlah sel radang akut alveoli paru, begitu pula sebaliknya.

\section{BAHASAN}

Asap rokok memberikan dampak pada kesehatan. Kandungan radikal bebas pada asap rokok akan memicu munculnya Stres oksidatif. Pada penelitian ini dapat diketahui bahwa pemberian asap rokok memberikan dampak pada penurunan SOD dan peningkatan jumlah sel radang. Pada kelompok kontrol positif $(\mathrm{K}+)$ yaitu kelompok perlakuan yang tidak mendapatkan paparan asap rokok didapatkan nilai SOD yang paling tinggi di antara kelompok perlakuan lainnya yaitu rata-rata 81,19 unit per cc. Kondisi tersebut berbeda pada kelompok kontrol negatif (K-) yaitu kelompok yang dipapar dengan asap rokok, kadar SOD pada kelompok tersebut paling rendah diantara kelompok lainnya yaitu rata-rata sebesar 52,27 unit/cc. Radikal bebas pada asap rokok menyebabkan penurunan kadar SOD untuk mengatasi kondisi radikal bebas. SOD merupakan enzim yang berperan penting dalam melindungi sel dari kondisi Stres oksidatif. ${ }^{5}$

Sedangkan jumlah sel radang akut alveoli akan meningkat dengan adanya paparan asap rokok. Berbeda dengan kelompok kontrol positif $(\mathrm{K}+)$, pada kelompok kontrol negatif (K-) jumlah sel radang alveoli paru lebih banyak yaitu ratarata sebesar 32,36. Hal tersebut menunjukkan bahwa radikal bebas akibat asap rokok menyebabkan adanya stres oksidatif yaitu kondisi dimana radikal bebas melebihi kapasitas antioksidan dalam tubuh. Hal ini menyebabkan adanya reaksi inflamasi yang mengarah pada 
penumpukan sel radang pada organ paru, termasuk alveoli. Kondisi ini jika terjadi secara terus menerus akan menyebabkan adanya kelainan pada saluran pernafasan.

Dari hasil korelasi menunjukkan bahwa ada hubungan antara kadar SOD dengan jumlah sel radang akut pada alveoli dengan kekuatan yang besar dan hubungan yang berlawanan $(p=0,000 ; r=-0,937)$. Artinya bahwa semakin rendah kadar SOD maka semakin tinggi jumlah sel radang akut alveoli. Superoksid Dismutase atau SOD merupakan enzim antioksidan yang memegang peranan penting dalam melindungi sel dari Stres oksidatif dan secara tidak langsung menjaga keseimbangan dari berbagai macam radikal bebas yang bersifat toksik bagi sel. ${ }^{5}$ Pada penelitian ini adalah radikal bebas yang dihasilkan oleh asap rokok. Dengan paparan asap rokok tersebut, SOD melakukan fungsinya dalam melindungi sel. Mekanisme kerja SOD adalah dengan mengkatalisa dismutase superoksid menjadi hidrogen peroksida $\left(\mathrm{H}_{2} \mathrm{O}_{2}\right)$ dan oksigen. ${ }^{17}$ Sehingga paparan asap rokok pada penelitian ini menyebabkan turunnya kadar SOD dan berdampak pada peningkatan jumlah sel radang akut alveoli paru.

Daun ubi jalar ungu atau PSPL dengan kandungan polifenol yang tinggi yaitu sebesar 1805 mgGAE per 100 gram dalam bentuk tepung memberikan efek yang positif pada penelitian ini. Pada semua kelompok perlakuan yang diberikan PSPL bersamaan dengan paparan asap rokok (P1, P2, P3) menunjukkan peningkatan kadar SOD dan penurunan jumlah sel radang akut alveoli dibandingkan kelompok yang hanya diberikan paparan asap rokok tanpa PSPL. Semakin besar dosis yang diberikan menunjukkan hasil yang semakin baik. Hal ini menunjukkan bahwa ternyata PSPL dengan kandungan polifenolnya dapat memperbaiki kondisi Stres oksidatif akibat paparan asap rokok. Hasil pada penelitian ini sejalan dengan hasil positif pada penelitian yang dilakukan oleh Wen-Hsin Chang,et.al, 2007 yaitu konsumsi PSPL dapat meningkatkan secara signifikan respon limfosit untuk menginduksi mitogen dalam meningkatkan NK cell, IL-2 dan IL-4. ${ }^{12}$ Selain itu, polifenol dari PSPL mampu menghentikan reaksi rantai radikal bebas pada peroksidasi lipid dengan mendonorkan elektron pada peroksil radikal asam lemak sehingga dapat menghentikan tahapan propagasi dan pada akhirnya radikal bebas dapat berkurang. Penelitian lain juga menunjukkan pemberian daun ubi jalar ungu sebesar $200 \mathrm{~g} /$ hari selama 2 minggu dapat meningkatkan total polifenol di dalam plasma dan berkurangnya oksidasi LDL.18 Tepung PSPL yang diberikan pada penelitian ini selain kaya akan polifenol juga mengandung vitamin seperti Beta karoten, Vitamin $B 2$, Vitamin $C$ dan $E$ yang juga memiliki efek sebagai antioksidan. ${ }^{19}$

\section{SIMPULAN DAN SARAN}

\section{Simpulan}

Berdasarkan hasil penelitian, dapat disimpulkan bahwa terdapat hubungan yang kuat antara kadar SOD dan jumlah sel radang akut alveoli paru pada tikus wistar yang medapatkan PSPL, dimana semakin tinggi kadar SOD maka semakin rendah jumlah sel radang akut alveoli paru.

\section{Saran}

Perlunya tambahan variasi dosis sehingga dapat diketahui dosis toksik akibat pemberian dalam jumlah yang berlebih serta perlunya pengembangan pemanfaatan PSPL sebagai upaya diversifikasi pangan.

\section{RUJUKAN}

1. Jaya, Muhammad. Pembunuh Berbahaya Itu Bernama Rokok. Yogyakarta: Riz'ma, 2009

2. Susanna-Dewi, Hartono-Budi, dan Fauzan-Hendra. Penentuan Kadar Nikotin dalam Asap Rokok. Makara Kesehatan. 2003;7(2): 7-14.

3. Kirkham P, Rahman I. Oxidative Stress in asthma and COPD-Antioxidants as a Theurapeitic Strategy. North Sussex: Noviartis Institutes for Biochemical Research, 2005.

4. Makker K, Ashok A, and Rakesh S. Oxidative Stress \& Male Infertility. Indian J Med Res. 2009;129(April):357-367

5. Touati, T. Regulation and Protective Role of the Microbial Superoxide Dismutase. In: Molecular Biology of Free Radical Scavenging System. S.l: Cold Spring Press, 1992.

6. Stevenson CS, Koch LG, Britton SL. Aerobic Capacity, Oxidant Stress, and 
Chronic Obstructive Pulmonary Disease A New Take on an Old Hypotesis. Pharmacology \& Theurapeutics. 2006; 110 (1): 71-82.

7. Abbas, NF, Richard M. Robbins Basic Pathology. S.I:Saunders, 2005.

8. Nurliani A, Heri B, Rusmiati. Efek Antioksidan Ekstrak Bulbus Bawang Dayak pada Gambaran Histopatologis Paru-paru Tikus yang Dipapar Asap Rokok. Biosciente. 2012;9(1):60-69

9. Marianti, Aditya. Aktivitas Jus Tomat pada Pencegahan Kerusakan Jaringan ParuParu Mencit yang Dipapar Asap Rokok. Biosaintifika. 2009;1(1) : 1-10

10. Chang WH, Hu SP, Huang YF, Yeh TS, Liu JF. Effect of Purple Sweet Potato Leaves Consumtion on Excercise-Induced Oxidative Stress and IL-6 and HSP72 Levels. J Appl Physiol. 2010;109(6):17101715.

11. Chang WH, Chen CM, Hu SP, Kan NW, Chiu CC, Liu JF. Effect of Purple Sweet Potato Leaf Consumtion on The Modulation of The Antioxidative Status in Basketball Players during Training. Asia Pac J Clin Nutr 2007; 16(3) : $455-461$.

12. Chang $\mathrm{WH}$, Chen $\mathrm{CM}, \mathrm{Hu} S \mathrm{SP}, \mathrm{Kan} \mathrm{NW}$, Chiu CC, Liu JF.. Effect of Purple Sweet Potato Leaves Consumtion on The Modulation of The Immune Respone in Basketball Players during Training Period. Asia Pac J Clin Nutr 2007; 16(4) : 609 615.
13. Chen CM, Li SC, Lin YL, Hsu CY, Shieh MJ, Liu JF. Consumption of Purple Sweet Potato Leaves Modulated Human Immune Respone : T- Lymphocytes Fungstion, Litic Activity of Natural Killer and Antibody Production. World J Gastroenterol 2005; 11(37) : $5777-5781$

14. Hanafiah, Kemas Ali. Rancangan Percobaan : Teori dan Aplikasi Edisi 3. Jakarta: Rajarafindo Persada , 2008.

15. Kusumawati, Diah. Bersahabat dengan Hewan Coba. Yogyakarta: Gajah Mada University Press, 2004

16. Marianti, Aditya. Aktivitas Jus Tomat pada Pencegahan Kerusakan Jaringan ParuParu Mencit yang Dipapar Asap Rokok. Biosaintifika. 2009;1(1) : 1-10

17. Wander, RJA, Denis S. Identification of Superoxide Dismutase in Rat Liver Peroxisome. Biochemia et Biophysica Acia. 1991;1115: 252-262

18. Chen CM, Lin YL, Chen CY, Hsu CY, Shieh MJ, Liu JF. Consumption of Purple Sweet Potato Leaves Decrease Lipid Peroxidation and DNA damage in Humans. Asia Pac J Clin Nutr. 2008; 17 (3): 408-414

19. Antia BS, Akpan EJ, Okon,PA, Umoren IU 2006. Nutritive and Anti-Nutritive Evaluation of Sweet Potatoes (Ipomoea batatas) Leaves. Pakistan Journal of Nutrition 5 (2): 166-168. 